\title{
Interactive Response Technology User Acceptance Testing Certificate
}

National Cancer Institute

\section{Source}

National Cancer Institute. Interactive Response Technology User Acceptance Testing

Certificate. NCI Thesaurus. Code C115470.

Official records that confirm the status of the user acceptance testing done on the interactive response technology. 